\title{
YouTube Approach Sebagai Media Pembelajaran Komunikasi Digital Preschool di Masa Pandemi Covid-19
}

\author{
Fathimah Aqilah \\ Program Studi Komunikasi, Universitas 'Aisyiyah Yogyakarta, Indonesia \\ Fathimahaqilah155@gmail.com \\ Mega Ardina \\ Program Studi Komunikasi, Universitas 'Aisyiyah Yogyakarta, Indonesia \\ komunikasi@unisayogya.ac.id \\ Diserahkan: 1 Juni 2021; Direvisi: 10 Juni 2021 ; Diterima: 10 Juni 2021
}

\begin{abstract}
Social media makes it easier for humans to communicate with other humans and get information from various fields such as politics, social, economy, health, and even education. At the turn of 2019 to 2020, human activities are carried out online due to the emergence of the corona virus disease (Covid-19). Learning is also carried out using the online or online method so that the teaching and learning process continues. Peschool SC Club uses TouTube as a learning medium during the pandemic. The independence of children remains a top priority and the role of $Y$ ou Tube is very important as a learning medium. The purpose of this study is to determine the important role of YouTube on children's independence at the Preschool SC Club Wonosobo. This research method uses descriptive qualitative, presenting and knowing in depth the factors that influence the research. Data collection was obtained from observations to research locations, as well as interviews with several parents and teachers of SC Klab.. The conclusion of this study is that the use of YouTube on children's independence is influenced by the self-confidence of preschool children as shown by appearing in public from an early age, the creativity level of preschool children increases as shown by pouring their creative ideas into assignments, delivering material through YouTube in an interesting way provides motivation to study hard as shown by the readiness of children every time learning begins, preschool children can adapt to online learning / using YouTube as shown by the enthusiasm of children when learning takes place.

Keywords: Social Media, Digital Communication Learning, Covid-19 Pandemic.
\end{abstract}

\begin{abstract}
Abstrak
Media sosial memudahkan manusia untuk berkomunikasi dengan manusia lain dan mendapatkan informasi dari berbagai bidang seperti politik, sosial, ekonomi, kesehatan, bahkan pendidikan. Pada pergantian tahun 2019 hingga 2020, aktivitas manusia dilakukan secara online akibat munculnya penyakit virus corona (Covid-19). Pembelajaran juga dilakukan dengan menggunakan metode online atau online agar proses belajar mengajar tetap berjalan. Peschool SC Club menggunakan YouTube sebagai media pembelajaran di masa pandemi. Kemandirian anak tetap menjadi prioritas utama dan peran YouTube sangat penting sebagai media pembelajaran. Tujuan dari penelitian ini adalah untuk mengetahui peran penting YouTube terhadap kemandirian anak di PAUD SC Club Wonosobo. Metode penelitian ini menggunakan deskriptif kualitatif, menyajikan dan mengetahui secara mendalam faktor-faktor yang mempengaruhi penelitian. Pengumpulan data diperoleh dari observasi ke lokasi penelitian, serta wawancara dengan beberapa orang tua dan guru SC Klab. Kesimpulan dari penelitian ini adalah penggunaan youtube terhadap kemandirian anak dipengaruhi oleh rasa percaya diri anak prasekolah seperti yang ditunjukkan dengan tampil di depan umum sejak dini tingkat kreativitas anak prasekolah meningkat yang ditunjukkan dengan menuangkan ide kreatifnya ke dalam tugas, penyampaian materi melalui youtube dengan cara yang menarik memberikan motivasi untuk giat belajar yang ditunjukkan dengan kesiapan anak setiap kali pembelajaran dimulai, anak-anak prasekolah dapat beradaptasi dengan pembelajaran online/menggunakan youtube yang ditunjukkan dengan antusiasme anak-anak saat pembelajaran berlangsung.

Kata Kunci: Media Sosial, Pembelajaran Komunikasi Digital, Pandemi Covid-19.
\end{abstract}




\section{PENDAHULUAN}

Pergantian tahun 2020 ke 2021 merupakan awal yang baru untuk seluruh masyarakat di dunia, karena dunia dikejutkan dengan penyakit yang menyebar hampir ke seluruh negara. Penyakit tersebut dikenal dengan virus corona (Covid-19) dan setiap orang yang terinfeksi akan mengalami gejala mulai dari ringan hingga sedang. Presiden Joko Widodo meminta agar masyarakat meningkatkan kewaspadaan terhadap penyebaran virus corona, serta meminta agar masyarakat mulai mengurangi aktivitas di luar rumah (Pamungkas, 2020).

Kasus Covid-19 di dunia pada akhir tahun yaitu 31 Desember 2020 mencapai 83.060.276 dengan 1.812.046 kematian, (Verdiana, 2020). Kasus yang masih terjadi mengakibatkan pada tahun 2021 diperkirakan kasus dapat bertambah dan terus menyebar. Kasus infeksi virus corona di dunia hingga 1 Januari 2021 tercatat sebanyak 83.730.515 kasus (Aida, 2021). Peningkatan kasus Covid-19 juga dialami oleh negara berkembang seperti Negara Indonesia.

Kasus konfirmasi positif Covid-19 pada 1 Januari 2021 di Indonesia mencapai 751.270 kasus, 22.329 kematian, dan 617.936 sembuh dan mengalami peningkatan dengan data sebelumnya tercatat 743.198 kasus, 22.138 kematian, dan 611.097 sembuh (Kurniawan, 2021). Penyebaran Covid-19 yang terus menambah berdampak besar dari berbagai bidang yaitu sosial, politik, budaya, hingga pendidikan. Selain itu, masyarakat perlu mengikuti himbauan dari pemerintah seperti menjaga jarak, memakai masker, dan mengurangi intensitas bertemu secara langsung.

Presiden Jokowi Widodo menyampaikan bahwa kebijakan belajar dari rumah, bekerja dari rumah, dan ibadah di rumah perlu terus digencarkan untuk mengurangi penyebaran virus covid-19 (Ihsanuddin, 2020). Kebijakan yang disampaikan oleh pemerintah memberikan metode yang baru pada bidang pendidikan dengan memanfaatkan kemajuan teknologi saat ini.

Pemanfaatan kemajuan teknologi berupa internet memberikan kemudahan untuk antar individu saling berkomunikasi. Pengguna internet di Indonesia masuk peringkat kelima sebanyak 143,26 juta per Maret 2019, selisih tipis dengan Brazil yang memiliki pengguna internet sebanyak 149,06 juta (Jayani, 2019). Pemanfaatan internet digunakan untuk mengakses berbagai macam media sosial, salah satunya yaitu TouTube.

YouTube merupakan salah satu bentuk media sosial berbasis video yang mulai naik daun sejak 5 tahun yang lalu. Dilansir dari statistik dalam situsnya sendiri. YouTube memiliki lebih dari satu milyar pengguna yang merupakan hampir sepertiga semua pengguna internet (David, Mariam, \& Stefi, 2017). YouTube adalah platfom media sosial yang memuat berbagai macam video sehingga dapat dlihat oleh siapapun dan dimanapun dengan terhubung internet. TouTube memiliki kebebasan durasi, dan semua video yang di-upload tidak memerlukan biaya/ gratis hanya dengan memiliki akun google yang terhubung dengan YouTube (Tutiasri, Laminto, \& Nazri, 2020). YouTube juga dapat diakses dari berbagai kalangan mulai dari orang dewasa hingga anak usia dini.

YouTube memberikan akses untuk menonton video secara bebas dan dapat dilihat oleh siapapun. Konten yang ditampilkan rouTube salah satunya tentang pendidikan. YouTube dapat menjadi media pembelajaran pada masa pandemi Covid-19. Mulai dari mahasiswa hingga anak usia dini. Salah satu tempat pembelajaran yang sudah memakai YouTube sebagai media pembelajaran yaitu Preschool SC Klab Wonosobo.

Preschool SC Klab merupakan salah satu sekolah yang mengadopsi sistem pembelajaran di Jepang. Dilansir dari sekolahdijepang.com, anak usia balita batita (hoiken) sudah dilatih dan diarahkan untuk mandiri seperti makan sendiri, betanggung jawab ajan kebersihan dan kerapian. Sedangkan untuk pembelajaran TK (youchien) di Jepang lebih memprioritaskan pengembangan fungsi tubuh dan jiwa secara seimbang, etika dasar, semangat kemandirian, kemampuan sosialisasi, komunikasi, mengarahkan minat dan bakat, serta tetap diajarkan membaca, menulis, dan menghitung dengan suasana yang sangat menyenangkan seperti bermain dan bernyanyi. Preschool SC Klab mengaplikasikan sistem tersebut salah satunya pada anak 4-6 tahun/ setara dengan Taman KanakKanak (TK) dengan berfokus pada membentuk kemandirian pada anak. 


\section{KAJIAN PUSTAKA}

Penerapan konsep pembelajaran di Preschool SC Klab yaitu pembelajaran yang Fun, Aktif (Active), dan memberi nilai manfaat (Valuable) dalam mewujudkan pendidikan dengan penguatan karakter dan kemandirian. Semua proses belajar mengajar dilaksanakan dengan senang hati sehingga anak-anak dapat dibimbing, diarahkan, dan dikembangkan potensi anak secara optimal tanpa target dan beban tetentu. Preschool SC Klab mempunyai tagline yaitu Cerdas Itu Perlu Tapi Anak Berhak Bahagia. Tujuannya yaitu membentuk anak menjadi indovidu yang mandiri dan memiliki kesiapan melanjutkan tahapan pendidikan berikutnya. Konsep pembelajaran juga diterapkan pada masa pandemi di tahun 2020 dengan sitem pembelajaran daring melalui channel YouTube Sanggar Cilik.

Berdasarkan penelitian oleh Rahma, Utami, \& Hapidin (2016) tentang Kemandirian Anak Usia 56 Tahun Di Komunitas Lingkungan Pemulung bertujuan untuk mendapatkan gambaran informasi dan data empiris mengenai kemandirian anak usia 5-6 tahun di komunitas lingkungan pemulung TPST Sumur Batu, Bantar Gebang. Hasil dari penelitian ini adalah kemandirian anak usia 5-6 tahun di komunitas lingkungan pemulung dibentuk oleh peran dan sikap orang tua serta peran lingkungan.

Perbedaan dari dua penelitian tersebut yaitu fokus pada kasus penelitian kemandirian anak melalui penggunaan YouTube Sanggar Cilik, usia anak mulai umur 4-6 tahun, proses pembelajaran yang diberikan menggunakan metode daring/ online, lokasi penelitian di Preschool SC Klab Wonosobo, serta dilakukan pada saat pandemi Covid-19.

Proses pembelajaran daring di Preschool SC Klab menggunakan media YouTube dengan nama channel YouTube Sanggar Cilik. Media tersebut dibuat pada Maret 2020 setelah himbauan pemerintah untuk belajar dari rumah/daring selama pandemi covid-19 khususnya di Wonosobo. YouTube Sanggar Cilik dibuat untuk memudahkan anak-anak dalam proses belajar selama pandemi covid-19. Pembuatan video pembelajaran tidak hanya untuk muid TK saja, dimulai dari kategori anak daycare, playgroup/ kelompok bermain, TK, dan SD. Pembuatan video pembelajaran dilakukan 1 minggu sebelumnya yang nantinya akan di-upload pada mingu berikutnya. Proses peng-upload-an dilakukan setiap 1 minggu pada pukul 08.00 pagi, 1 video pembelajaran 1 tugas yang artinya ada 5 video dan 5 tugas untuk setiap minggunya. Namun pada beberapa bulan terakhir ini pembuatan video hanya 1 video saja untuk 5 tugas. Tujuannya agar anak-anak tidak selalu berinteraksi dengan gadget apalagi setelah melihat YouTube.

Sesuai dengan perkembangan teori Computer Mediated Communication (CMC) adalah teori yang merekam proses komunikasi manusia melalui computer yang melibatkan orang terletak dalam konteks tertentu, terlibat dalam proses pembentukan media untuk berbagai keperluan. Teori ini mempunyai jangkauan yang cukup luas dalam penggunaan new media. Konsep baru tentang CMC ini menarik pada pengejewantahan komunikasi dengan psikologi. The Sosical Psychology of Telecommunications yang berfokus pada audio konfrerensi dan telekonferensi, menjelaskn kepada para penelito awal CMC, adanya isyarat nonverbal dan frekuensi pengambilan keputusan pada pengaplikasian teori CMC ini. Dalam teori ini juga menggunakan konsep penti gterkait social presence yang menyatakan bahwa, actor sosial mendapatkan pengalaman sesuai dengan isyarat atau lambang-lambang sosial yang terdapat dalam berbagai media komunikasi menjadi sesuatu yang menarik untuk diteliti.

\section{METODE PENELITIAN}

Penelitian kualitatif sering disebut metode penelitian naturalitik karena penelitian dilakukan pada kondisi yang alamiah. Metode ini digunakan untuk mendapatkan data yang mendalam dan suatu data yang mengandung makna/ data yang sebenarnya dan data yang pasti (Sugiyono, 2013).

Menurut Arikunto dalam (Prabowo \& Heriyanto, 2013) penelitian deskriptif adalah mengumpulkan data berdasarkan faktor-faktor yang menjadi pendukung terhadap objek penelitian, kemudian menganalisis faktor-faktor tersebut untuk dicari peranannya. Metode pendekatan deskriptif kualitatif yaitu metode yang berkaitan dengan objek penelitian dengan penyajian data secara lebih mendalam terhadap objek penelitian. Metode penelitian deskriptif dalam penelitian ini, bertujuan 
untuk menyajikan dan mengetahui secara lebih dalam yang berkaitan dengan faktor-faktor yang mempengaruhi penelitian tersebut.

Kecanduan akan munculnya perasaan pengguna media YouTube sebagai media pembelajaran yang akan merasa "mampu" menjelajah duniamelalui computer, "mampu" mencapai ilusi kedekatan dan ketertarikan dengan computer secara intim, dan mampu mengekspresikan diri dengan caranya sendiri serta mampu mendapatkan pembenaran atau justifikasi menjadi titik keberangkatan peneliti mengkaji penelitian yang menggunakan media YouTube ini.

Peneliti melakukan penelitian selama kurun waktu 3 bulan di Preschool SC Klab Wonosobo. Pengmpulan data diperoleh dari observasi ke lokasi penelitian, serta wawancara dengan beberapa wali murid dan guru SC Klab. Selanjutnya, data yang terkumpul akan diolah dan dianalisis dengan reduksi data, sajian data, dan penaikan kesimpulan dari data yang sudah diambil oleh peneliti.

\section{HASIL DAN PEMBAHASAN}

HASIL

Pengaruh penggunaan YouTube pada umumnya dapat mengakibatkan kecanduan pada anak sehingga dapat mempengaruhi kemandirian anak. Pre School SC Klab Wonosobo memiliki tujuan yang berkaitan dengan kemandirian anak. Sekolah ini menekankan pada karakter kemandirian anak sejak dini, sehingga proses pembelajran melalui YouTube dapat berpengaruh pada kemandirian anak seperti yang diungkapkan oleh responden orangtua,

"Kalau ada tugas video gitu sesuai dengan yang dia suka si, misalkan menyanyi dia masih krang PD karena mungkin enggak hafal liriknya gitu ya tapi kalau berdoa gitu ya PD aja. Tapi misal doa bercermin itu kan jarang ya nah dia kurang hafal ya jadi enggak PD. Sukanya dia si Mba gimana atau bidangnya dia aja si" (Rosi, 2021).

"Pas proses waktu pengerjaan video gitu Mba, kebetulan bahasa jawanya kendel jadi enggak ada masalah.

Jadi kalau pas bikin tugas saya vidioin. Alhamdulillah si kalau malu-malu tu enggak Mba, dia enggak pernah malu" (Sisca, 2021).

Kepercayaan diri dalam wawancara ini dapat dilihat bahwa tingkat kepercayaan diri pada anak dipengaruhi oleh materi yang dikuasai oleh anak sendiri. Hal ini berkaitan dengan teori yang disampaikan oleh Susanto dalam (Pariera \& Atal, 2019) bahwa anak yang memiliki kepercayaan diri akan melakukan hal atau sesuatu dengan berani, serta dapat menentukan pilihan sesuai dengan kehendaknya. Walaupun proses pembelajaran menggunakan YouTube Sanggar Cilik namun tidak mengurangi rasa percaya diri anak yang mengusai materi, anak yang kurang percaya diri disebabkan oleh materi yang belum dikuasai anak dan menjadi evaluasi guru dalam penyampaian materi.

Ciri kemandirian anak selanjutnya yaitu memiliki motivasi yang tinggi. Motivasi dapat mempengaruhi kemandirian anak dalam belajar terlebih dalam pembelajaran daring ini. Anak-anak perlu mendapatkan motivasi untuk belajar melalui YouTube namun masih perlu ada pengawasan sehingga anak-anak tidak menjadi kecanduan bermain gadget. Para guru menggunakan YouTube Sanggar Cilik tidak hanya untuk menyampaikan materi namun terdapat kalimat untuk memotivasi anak belajar seperti yang diungkapkan oleh responden orangtua,

"Kakak-kakaknya memang mengemas video itu sangat simpel dan mudah untuk dipahami dan mengerti untuk anak. Kakak-kakaknya itu dalam membuat video isinya udah direncanakan benar-benar simpel. Tidak terpaut dengan KD hanya untuk live skill dan karakternya dahulu yang diutamakan. Jadi memang jarang ada kegiatan seperti yang membutuhkan barang-barang yang harus beli karena pada saat itukan memang benar" sedang lockdown"(Rosi, 2021).

"Penyampaian dari Kakak-kakaknya juga pinter Mba, pembuatan videonya itu Mba. Jadi anak saya merasa senang dan juga kreatif bikin videonya. Materi yang diberikan kakaknya juga enggak sulit, jadi masih bisa diikuti sama anak-anak. Bahkan anak saya juga menayakan videonya mana gitu Mb" (Sisca, 2021 ).

Jadi YouTube Sanggar Cilik memiliki keterkaitan dalam motivasi anak dalam belajar terutama dalam penyampaian materi. Motivasi yang tinggi pada anak menyebabkan anak semakin ingin belajar 
walaupun dengan pembelajaran daring. Hal ini berkaitan dengan faktor pembentukan perilaku seperti yang disampaikan oleh (Purbohastuti, 2019) bahwa motivasi adalah dorongan untuk bertindak mencapai suatu tujuan tertentu, hasil dari dorongan dan gerakan ini diwujudkan dalam bentuk perilaku. Perilaku dalam penelitian ini adalah anak menjadi memiliki motivasi yang tinggi dalam belajar melalui YouTube Sanggar Cilik. Konten dan desain yang ditampilkan dalam YouTube Sanggar Cilik membuat anak senang dan menambah kreatifitas anak selama kegiatan belajar berlangsung.

Kemandirian anak berkaitan dengan kreatifitas dan inovasi yang dimiliki oleh anak seperti yang diungkapkan responden orangtua,

"Anak saya senang tadi itu Mba, dari materi yang bisa dipahami sama anak jadinya anak bisa mengikuti. Misal ada tugas menghias makanan, atau membuat ikan dari kaleng bekas itu malah anak kadang bikin inovasi sendiri, menghias sendiri gitu Mba. Kakaknya kreatif jadi anak juga ikutan dengan cara anak sendiri" (Rosi, 2021).

"Iya Mba gampang banget, karena tutorialnya, step by step ada semua jadi anak ngikutin yang ada di YouTube itu. Misal ya Mba ada tema tentang experiment bikin kayak campuran warna ini dicampu warna ini jadinya warna ini, jadi anak nanti bisa nambahin buat hiasan mereka sendiri gitu" (Sisca, 2021).

Hal ini berkitan dengan ciri kemandirian anak yang dijelaskan oleh Susanto dalam (Pariera \& Atal, 2019), yaitu pada anak usia dini salah satu ciri anak yang memiliki karakter mandiri, menyukai dan selalu ingin mencoba hal-hal baru. Anak dapat menuangkan ide kreatifnya kedalam tugas dari guru, yang disampaikan melalui YouTube Sanggar Cilik. Kreatifitas juga dilakukan oleh guru ketika memberikan materi melalui YouTube Sanggar Cilik. Kreatifitas tersebut diungkapkan oleh guru,

"Kita sering berrdiskusi, bertukar pikiran gitu sama teman-teman, gimana nih bia enggak jenuh dan anakanak tu bisa tertarik gitu Mba. Nah kita buat kolaborasi gitu Mba misalnya, guru utamanya itu ke tari, musik, kempo nah bisa kolaborasi dengan bahasa inggris, jepang gitu Mba. Jadi materinya enggak cuma menghafalkan, bernyanyi, menyebutkan benda-benda, atau menirukan gerakan hewan yang kesannya itu-itu aja" (Hikmah, 2021).

"Materi videonya beda-beda. Kalau itukan biasanya kita kan bikin planning nih untuk satu minggu kedepan itu kita mau ngerjain apa si. Nah kita suka breafing guru/kakak-kakak TK tukar ide. Biar gk bosen kan kita kayak yang dilihat tu kok kita lagi, kakak-kakak lagi, nah itu kita suka kolaborasi. Nah waktu itu kita sempetlah kolaborasi. Misalnya nih, untuk tempat sendiri itu kita biasanya pindah-pindah Mba gak melulu disekolah terus gitu. Misalkan kita kadang ke sawah, kadang kita ya kemana gitu loh" (Elma, 2021).

Pembelajaran daring melalui YouTube Sanggar Cilik menumbuhkan rasa tanggungjawab dalam diri anak. Anak merasa memiliki tugas yang harus dikerjakan setelah mendapatkan informasi dari grup kelas seperti yang diungkapkan oleh responden orangtua,

"Anak saya itu kadang menanyakan mana videonya Bu, padahal Mba itu hari Sabtu jadi malah rajin gitu Mba. Pernah waktu enggak mengerjakan tugas ya karena saya sendiri yang sibuk jadi enggak ngerjain gitu Mba, anak saya lihat video YouTube Sanggar Cilik terus dia ngomong sama saya kok aku belum ngerjain ini ya Bu. Daya ingatnya tajam gitu. Pernah juga guru kasih lihat video anak-anak yang lain, lalu anak saya ngomong sama saya gini kok Daris udah ngerjain aku belum. Nah itu kadang saya kalau yang terlambat langsung menguhubungi kakaknya kalau terlambat ngumpulin tugasnya" (Rosi, 2021).

"Pas ada deadline gitu terus belum ngumpulin saya langsung japri ke kakaknya kalau terlambat gitu, tapi masih mengerjakan tugas. Pernah suatu hari saya kan pulang malam, anak saya sudah tidur terus paginya saya juga kebetulan pergi pagi dan anak saya belum bangun. Akhirnya dia enggak mengerjakan tugas, itupun 1 atau 2 kali gitu Mba. Saya akalin gini Mba, ketika pagi ngerjain tugas/ngirim video sebelum saya ke toko. Tugasnya dikerjakan dulu sama anak saya, pokoknya harus kelar dan sebelum jam 9 pagi sudah dikumpulkan. Tapi waktu itu saya sibuk bener-bener sibuk Mba jadi enggak ngerjain tugas. Anak saya juga menanyakan tugasnya kok belum dikerjakan atau tugasnya yang ini aku belum bikin video Mah" (Sisca, 2021).

Berdasarkan wawancara di atas rasa tanggungjawab anak akan mengerjakan tugas walaupun tugas tersebut terlambat untuk dikumpulkan. Menurut Susanto dalam (Pariera \& Atal, 2019) menjelaskan 
bahwa anak yang memiliki karakter mandiri cenderung akan menerika konsekuensi dari keputusan yang telah diambil dan bertanggungjawab atas keputusan dari anak usia dini dalam taraf yang masih wajar. Anak-anak akan menerima konsekuensinya ketika tidak mengumpulkan tugas yaitu tidak mendapatkan reward ketika tugas dikerjakan tepat waktu atau sesuai kreatifitas anak.

Ciri kemandirian selanjutnya yaitu anak mudah beradaptasi dengan lingkungan yang baru. Lingkungan yang baru pada penelitian ini pembelajaran secara daring melalui YouTube Sanggar Cilik. Proses pembelajaran juga mengalami perubahan yaitu PJJ/ Pembelajaran Jarah Jauh seperti yang diungkapkan pada wawancara dengan responden orangtua,

"Kalau dilihat dari awal pandemi ya mungkin beberapa harilah agak kaget mungkin ya. Mah kenapa kita gak sekolah biasanyakan mereka harus berangkat sekolah pagi. Sekarang gak boleh kemana-mana. Awal itukan emang bener-bener lockdown habis-habisan. Nah itu mungkin agak-agak ya mungkin cuma beberapa hari. Tapi setelah satu minggulah terus setelah itu anak-anak mulai terbiasa dengan ritme yang ada dikasih sama sekolah" (Rosi, 2021).

"Alhamdulillah anak tu bisa mengikuti Mba. Dari kakak-kakaknya juga ada challenge gitu Mba, jadi anak saya terutama nggak bosa dan ngkuitinnya seneng aja gitu Mba" (Sisca, 2021).

Hasil wawancara ini menunjukkan, bahwa pada masa pandemi covid-19 anak-anak tetap mendapatkan materi pembelajaran seperti biasanya dan dapat mengikuti dengan baik. Walaupun pembelajaran melalui daring, anak-anak tidak merasa bosan dan tetap giat untuk belajar. Secara keseluruhan, penggunaan YouTube Sanggar Cilik sebagai alternatif media pembelajaran sangat efektif. Anak-anak dapat dengan mudah dari pembelajaran tatap muka ke pembelajaran daring. YouTube Sanggar Cilik memiliki peran penting dalam proses komunikasi antara guru dan murid di Pre School SC Klab Wonosobo selama pandemi covid-19.

\section{PEMBAHASAN}

Pengaruh penggunaan YouTube pada umumnya dapat mengakibatkan kecanduan pada anak sehingga dapat mempengaruhi kemandirian anak. Preschool SC Klab Wonosobo memiliki tujuan yang berkaitan dengan kemandirian anak. Sekolah ini menekankan pada karakter kemandirian anak sejak dini, sehingga proses pembelajaran melalui YouTube yaitu YouTube Sanggar Cilik dapat berpengaruh pada kemandirian anak. Salah satu ciri dari kemandirian anak yaitu memiliki kepercayaan diri yang tumbuh pada diri anak sendiri.

Menurut Sumahamijaya dalam (Pariera \& Atal, 2019) kemandirian adalah kemampuan untuk melakukan kegiatan atau tugas sehari-hari sesuai dengan tahapan perkembangan dan kapasitasnya. Kemandirian berasal dari kata mandiri yang berarti dalam keadaan dapat berdiri sendiri, tidak bergantung kepada orang lain, dan menggunakan kekuatan sendiri. Kemandirian anak usia dini dapat dilihat melalui ciri-ciri yang disebutkan oleh Susanto dalam (Pariera \& Atal, 2019) yaitu memiliki kpercayaan diri, memiliki motivasi yang tinggi, kreatif dan inovatif, bertanggung jawab, dan mampu beradaptasi. Kemandirian anak dalam penelitian ini berhubungan dengan penggunaan YouTube untuk anak usia dini.

Menurut Budiargo dalam (David, Mariam, \& Stefi (2017), YouTube adalah video online dan yang utama dari kegunaan situs ini ialah sebagai media untuk mencari, melihat dan berbagi video yang asli ke dan dari segala penjuru dunia melalui suatu web. Kebebasan mencai dan melihat situs yang ada di YouTube, setiap orang yang memiliki akun google juga dapat mengunggah video yang mereka buat sendiri. Sehingga orang lain dapat melihat video yang asli dari channel YouTube, dan hanya dengan megketik nama channel TouTube yang dicari.

Pada penelitian ini guru sebagai komunikator bertugas untuk menyampaikan materi selama proses belajar mengajar. Penyampaian materi sama halnya dengan menyampaikan sebuah pesan. Materi yang disampaikan seperti pembelajaran menulis, menempel, merapikan tempat tidur, dan sebagainya. Materi ini disampaikan melalui YouTube Sanggar Cilik sebagai media alternatif pada saat pandemi covid-19. YouTube memberikan ruang belajar yang efektif untuk anak usia dini. Konten yang dibuat 
oleh para guru Pre School SC Klab sangat menarik, sehingga menumbuhkan motivasi anak untuk tetap belajar. Selain itu, anak-anak dapat melepas rindu dengan guru yang menjadi favorit dikelas dengan mengulang video yang ada di YouTube Sanggar Cilik. Isi atau materi yang diberikan mudah dan menarik jika diikuti oleh anak Pres School SC Klab Wonosobo.

Anak-anak Pre School SC Klab dalam pola komunikasi ini menjadi seorang komunikan yang menerima sebuah pesan dari komunikator yaitu guru. Komunikan akan memberikan efek atau respon ketika sudah menerima pesan dari komunikator. Anak-anak yang telah menonton atau belajar melalui YouTube Sanggar Cilik akan memberikan respon seperti mengerjakan tugas, menuangkan ide kreatif, dan merasa terhibur dengan bebagai permainan yang dibuat oleh guru. Pada penelitian ini peran YouTube menjadi media yang dibutuhkan/penting, terhadap kemandirian anak di Preschool SC Klab Wonosobo.

Penggunaan media YouTube, juga tidak selamanya menimbulkan efek positif. Efek negative sangat kentara yang peneliti temui dalam pengambilan data penelitian. Peneliti menemukan bahwa penggunaan YouTube yang memiliki intensitas yang tinggi atau sering, beriringan juga dengan tumpulnya daya analisis yang diterima oleh murid SC Klab Wonosobo. Hal ini dibuktikan dengan tidak adanya respon yang sepadan dengan input yang diberikan. Jika efek ini bersifat jangka panjang maka dapat dipastikan bahwa murid dapat mengkontekstualisasikan produsi budaya dari interaksi yang berjalan di dunia maya (face to computer).

\section{KESIMPULAN}

Berdasarkan rumusan masalah penelitian ini, maka dapat disimpulkan bahwa media YouTube Sanggar Cilik memiliki peran penting terhadap kemandirian anak yang meliputi kepercayaan diri, motivasi yang tinggi, kreatifitas dan inovatif, bertanggung jawab, dan mampu beradaptasi. Pertama, tingkat kepercayaan diri pada anak dipengaruhi oleh materi yang dikuasai oleh anak sendiri. Walaupun proses pembelajaran menggunakan YouTube Sanggar Cilik namun rasa kurang percaya diri disebabkan oleh materi yang belum dikuasai anak dan menjadi evaluasi guru dalam penyampaian materi.

Kedua, YouTube Sanggar Cilik memiliki peran dalam motivasi anak dalam belajar terutama dalam penyampaian materi. Motivasi yang tinggi pada anak menyebabkan anak semakin ingin belajar walaupun dengan pembelajaran daring. Konten dan desain yang ditampilkan dalam YouTube Sanggar Cilik membuat anak merasa senang dan menambah kreatifitas anak selama kegiatan belajar berlangsung.

Ketiga, kreatifitas dan inovasi anak semakin bertambah dengan adanya YouTube Sanggar Cilik. Anak-anak merasa senang dan ingin mencoba hal-hal baru dengan menuangkan ide kreatifnya didalam tugas yang diberikan oleh guru melalui YouTube Sanggar Cilik. Anak akan menuangkan ide kreatif ketika kegiatan belajar berlangsung, seperti membuat hiasan sendiri, ber-experiment sendiri, dan sebagainya.

Keempat, rasa tanggungjawab anak telihat dari tugas-tugas yang diberikan oleh guru. Anak yang memiliki kemandirian akan mengejakan tugas walaupun tugas tersebut terlambat untuk dikumpulkan. Anak-anak akan menerima konsekuensinya ketika tidak mengumpulkan tugas yaitu tidak mendapatkan poin/ nilai, akan mendapatkan poin ketika tugas itu dikerjakan, dan mendapat reward ketika tugas dikerjakan tepat waktu atau sesuai kreatifitas anak.

Kelima, walaupun pembelajaran melalui daring, anak-anak tidak merasa bosan dan tetap giat untuk belajar. Secara keseluruhan, penggunaan YouTube Sanggar Cilik sebagai alternatif media pembelajaran sangat efektif. Anak-anak mampu beradaptasi dari pembelajaran tatap muka ke pembelajaran daring. YouTube Sanggar Cilik memiliki peran penting dalam proses komunikasi antara guru dan murid di Preschool SC Klab selama pandemi covid-19. Walaupun Prechool SC Klab memiliki sistem yang mengadopsi sistem pembelajaran Jepang, namun peran YouTube Sanggar Cilik sangat penting terhadap kemandirian anak selama pandemi Covid-19. 


\section{REFERENSI}

Aida, N. R. (2021, Januari 1). Kompas. Dipetik Januari 20, 2020, dari Kompas.com: https://www.kompas.com/tren/read/2021/01/01/083100365/update-coona-1-januari-2021china-dan-perancis-konfirmasi-kasus

David, E. R., Mariam, S., \& Stefi, H. (2017). Pengaruh Konten Vlog dalam YouTube terhadap Pembentukan Sikap Mahasiswa Ilmu Komunikasi Fakultas Ilmu Sosial dan Politik Universitas Sam Ratulangi . e-journal "Acta Diurna” Volume VI. No. 1.

Doni, F. R. (Volume 3 No. 2 - 2017). Perilaku Penggunaan Media Sosial Pada Kalangan Remaja. IJSE- Indonesia Journal on Software Engineering.

Ihsanuddin. (2020, Maret 16). Kompas.com. Dipetik November 18, 2020, dari Kompas.com: http://amp.kompas.com/nasional/read/2020/03/16/15454571/jokowi-kerja-dari-rumahbelajar-dari-rumah-ibadah-di-rumah-perlu-digencarkan

Jayani, D. H. (2019, September 11). katadata. Dipetik November 18, 2020, dari databoks: htps://databoks.katadata.co.id/datapublish/2019/09/11/indonesia-peringkat-kelima-duniadalam-pengguna-internet

Kurniawan, E. (2021, januari 1). Tribunnewes.com. Dipetik januari 20, 2020, dari Tribunnews.com: https://m.tribunnews.com/amp/corona/2021/01/01/breaking-news-kasus-coronaindonesia-1-januari-202 1-bertambah-8072-kasus-total-751270-positif

Pamungkas, P. (2020, March 15). Tribunnewes.com. Dipetik November 18, 2020, dari Tribunnews.com: https://www.tribunnews.com/nasional/2020/03/15/instruksi-jokowikerja-belajar-ibadah-di-rumah-asn-boleh-tidak-ke-kantor-tapi-jangan-kendur

Pariera, M. I., \& Atal, N. H. (2019). Peningkatan Kemandirian Anak Usia 4-5 Tahun Melalui Bercerita. Jurnal PG-PAUD Trunojoyo : Jurnal Pendidikan dan Pembelajaran Anak Usia Dini, Volume 6, Nomor 1, April 2019, 37.

Prabowo, A., \& Heriyanto. (2013). Analisis Pemanfaatan Buku Elektronik (E-Book) oleh Pemustaka di Perpustakaan SMA Negeri 1 Semarang. Jurnal Ilmu Perpustakaan Volume 2, Nomor 2.

Purbohastuti, A. W. (2019). Perilaku Mahasiswa Terhadap Sosial Media. Jurnal Manajemen dan Bisnis, Volume XI, No.2, Fakultas Ekonomi dan Bisnis Univesitas Sultan Ageng Tirtayasa.

Putra, K. D., \& Jannah, M. (2013). Perkembangan Kemandirian Anak Usia Dini (Usia 4-6 Tahun) di Taman Kanak-Kanak Assalam Surabaya. https://ejournal.unesa.ac.id, 1-7.

Rahma, S., Utami, A. D., \& Hapidin. (2016). Kemandirian Anak Usia 5-6 Tahun di Komunitas Lingkungan Pemulung. Jurnal Ilmiah VISI PPTK PAUDNI - Vol.11 No. 1, 1-9.

Rahmat, P. S. (2009). Penelitian Kualitatif. EQUILIBRIUM, Volume 5, No. 9.

Rahmawati, W., \& Sugiantoro, H. A. (2019). Pola Jaringan Komunikasi Layanan Kesehatan Bagi Penyandang Disabilitas Korban Erupsi Gunung Merapi. Channel Junal Komunikasi Vol.7, No.2, pp. 97-104.

Sugiyono. (2013). Metode Penelitian Pendidikan Pendekatan Kuantitatif, Kualitatif, dan RङD. Bandung: Alfabeta.

Tutiasri, R. P., Laminto, N. K., \& Nazri, K. (2020). Pemanfaatan YouTube Sebagai Media Pembelajaran Bagi Mahasiswa di Tengah Pandemi Covis-19. Jurnal Komunikasi, Masarakat dan Keamanan (KOMASKAM), 4.

Verdiana, B. M. (2020, Desember 31). Liputan 6. Dipetik Januari 20, 2021, dari Liputan6.com: https://m.liputan6.com/global/read/4446063/update-covid-19-dunia-31-desember-2020tembus-83-juta-kasus-tertinggi-asia-di-india 